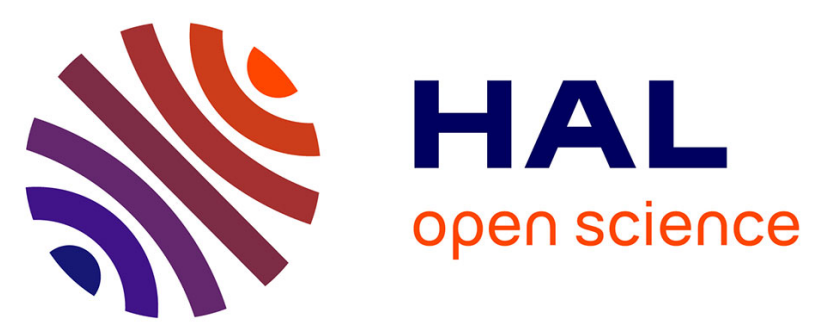

\title{
Monitoring water level in large trans-boundary ungauged basins with altimetry: the example of ENVISAT over the Amazon basin
}

F. Seyler, Stéphane Calmant, J. da Silva, N. Filizola, Emmanuel Roux, Gérard Cochonneau, Philippe Vauchel, Marie-Paule Bonnet

\section{To cite this version:}

F. Seyler, Stéphane Calmant, J. da Silva, N. Filizola, Emmanuel Roux, et al.. Monitoring water level in large trans-boundary ungauged basins with altimetry: the example of ENVISAT over the Amazon basin. Asia Pacific Remote Sensing Conference, Nov 2008, Nouméa, France. 10.1117/12.813258 . hal-01370629

\section{HAL Id: hal-01370629 \\ https://hal.science/hal-01370629}

Submitted on 23 Sep 2016

HAL is a multi-disciplinary open access archive for the deposit and dissemination of scientific research documents, whether they are published or not. The documents may come from teaching and research institutions in France or abroad, or from public or private research centers.
L'archive ouverte pluridisciplinaire HAL, est destinée au dépôt et à la diffusion de documents scientifiques de niveau recherche, publiés ou non, émanant des établissements d'enseignement et de recherche français ou étrangers, des laboratoires publics ou privés. 


\title{
Monitoring water level \\ in large trans-boundary ungauged basins with altimetry: the example of ENVISAT over the Amazon basin
}

\author{
Frederique Seyler ${ }^{1}$, Stephane Calmant ${ }^{2}$, Joecila da Silva ${ }^{3}$, Naziano Filizola ${ }^{4}$, Emmanuel Roux ${ }^{1}$, \\ Gerard Cochonneau ${ }^{5}$, Philippe Vauchel ${ }^{5}$, Marie-Paule Bonnet ${ }^{5}$
}

1.Institut de Recherche pour le Développement (IRD), Unité Espace (France)

2.Univ. Toulouse 3 (France), IRD, Laboratoire d'Etudes en Géophysique et Océanographie Spatiales (LEGOS)

3. Univ. Federal de Rio de Janiero (Brazil)

4. Univ. do Estado de Amazonas (Brazil)

5. Univ. Toulouse 3 (France), IRD, Laboratoire des Mécanismes et Transfert en Géologie (LMTG)

\begin{abstract}
Brasil and Bolivia have water plans projects on the Beni-Madeira river, a major tributary of the Amazon. There are four main tributaries to the Rio Madeira: the Guapore, the Mamore and the Beni rivers into the Bolivian territory, and the Madre de Dios River crossing the North of Bolivia, coming from Peru. Most parts of these rivers are very far from the Andean capital cities of Bolivia and Peru, unreachable for long periods of time. Very few gauging stations are in operation, either for the Bolivian or the Peruvian part, most of them being located at the Andes piedmont or near the confluence at the Brazilian border as they form the Madeira river. This situation is exemplary of large transboundary basins in the tropical part of the world.

We have computed 39 water level time series using ENVISAT altimetry data over the four tributaries of the Madeira and the Madeira itself. We present a preliminary study mostly conducted onto the Guapore river, in order to assess the quality of these time series for a variety of situations, but mostly narrow and meandering riverbeds. Comparison between water levels variation in the mainstream and within the inundations plains and lakes are drawn. We conclude by the perspectives offered by the combined use of radar altimetry and SAR imagery for the global monitoring of water resources, in large tropical transboundary basins.
\end{abstract}

Keywords : hydrology, floodplain, wetlands, water level, radar altimetry, transboundary basin, ungauged basin, Amazon basin.

\section{INTRODUCTION}

Observing the temporal and spatial variations in water stored or transiting through rivers, floodplains, wetlands and lakes is essential in many aspects. It is known that societies will lack freshwater in many parts of the world within a not too distant future, and that already one third of the world's population has no access to clean water ${ }^{1}$. Nonetheless, our knowledge of the terrestrial water balance is limited to some well measured basins of medium size, all located in temperate areas. The scientific community is well aware of the important role of equatorial water system in the global carbon cycle. Estimate of $\mathrm{CO}_{2}$ outgassing from Amazonian wetlands suggests that river systems are a source of $\mathrm{CO}_{2}$ an order of magnitude greater than the exportation to ocean of organic plus inorganic carbon ${ }^{2}$. But the uncertainties about processes involved in the alternatively dry and inuntaded floodplain, the volume of water transiting through this huge interface between land and water, and the net balance of these ecosystems are still great. These issues and the way we can reduce the uncertainties and improve our response to the climate change threats is strongly dependent on our ability to track the time variations of water stage in great tropical river systems.

Unfortunately, the conventional observations of water dynamics are scarce and unevenly spatially distributed, especially in tropical regions of the earth. Quoting Alsdorf et al., ${ }^{3}$, « there is a widespread recognition of the need for better observations and understanding of surface water distribution globally ». The Group on Earth Observations (GEO) was 
launched in response to this call, among others. This group, based on a partnership of governments and international organizations, is coordinating efforts to build a Global Earth Observation System of Systems, or GEOSS. One key issue for GEOSS « will be to combine water-level data from satellite-based radar altimeters with data from ground-level, insitu monitors. This will improve the ability of water managers to map the water cycles of major rivers ${ }^{4}$.

This paper will expose a preliminary study merging conventional water stage measurements with radar altimetric data. The study was conducted in the Madeira-Guapore basin. The region of the upper Rio Madeira is the southernmost extension of the Amazon Basin, at the Brazilian border with Bolivia and Peru. The area was opened up originally in the early part of the twentieth century by the contruction of a $366 \mathrm{~km}$ railroad between Porto Velho, capital city of Rondônia state in Brazil and Guajará-Mirim, on the Mamore river in Bolivia. Rondônia region is the Brazilian State with the fastest population growth in the recent past. There are water plans projects within the region, known in Brazil as « Complexo do Madeira », involving both Brazil and Bolivia. Four dams are planned, two on the upper Madeira between Porto Velho and Abuna, and two in Bolivia, in Guajara-Mirim and Cachuela Esperanza on the Rio Mamore, which is one of the four main tributaries of the Madeira river, along with the rivers Guapore, Beni and Madre de Dios. Guapore, Mamore and Beni are meandering rivers, flowing mostly South to North into the Bolivian territory, through extensive inundation plains, formed by a thousand of lakes of all form and size, called Llanos de Mojos. The fourth one, the Madre de Dios river, is crossing West to East the North of Bolivia, coming from Peru. Llanos de Mojos region is located far from the Andean capitals of Bolivia and Peru, unreachable for long periods of time. This large floodplain has a variable extension related to the alternating dry and rainy tropical seasons ${ }^{5}$, partly dry during Austral winter and reaching $150000 \mathrm{~km}^{2}$ at the end of the rainy season 6 . Seven altimetric gages, named "virtual gages », were computed on the upper Madeira, upstream of Porto Velho, 15 on the Guapore river, 14 on various lakes, floodplains and wetlands, and three on a tributary of the Mamore river, the rio Pacaas Novas. We will relate the methodologies involved, the results obtained, the validation of the altimetric data we could perform, and we will explore the ways we can use these data, integrated with conventional measurements, to improve our knowledge of the water temporal cycles in these remote, complicated, and in rapid transformation areas.

\section{MATERIAL AND METHODS}

\subsection{Study site}

The study is involving three distincts environments, which we will describe mostly from the observation of JERS-1 image mosaic. JERS-1 is an L-band spaceborne SAR system launched by the National Space Development Agency of Japan (NASDA) in February, 1992. In late 1995, JERS-I satellite entered into its Global Rain Forest Mapping (GRFM) phase and has been collecting high resolution SAR data over the entire tropical rainforest. These images of GRFM phase have been mosaicked at 100meters resolution over two periods chosen to best fit the dry season and the rainy season in the Amazon basin, from October to December 1995, and from March to May $1996^{7}$.

The first study site is the upper Madeira. From Porto Velho to Abuna, located $235 \mathrm{~km}$ upstream, at the confluence with the Beni river and the border with Bolivia, the Madeira river counts 15 water falls, which are natural obstacles to navigation. It leaves rapidly the cenozoic formation of the lower course, to enter holocene formations intermixed with precambrian formations of the Brazilian shield, often called Guapore shield (figure 1). At the border with Bolivia, marked on the figure 1 by the station of Abuna, it divides in four tributaries, from west to east : Madre de Dios, Beni, Mamore, Guapore.

The second part of the study encompass the upper Mamore from the confluence with the Beni river to the confluence with the Guapore river. Except the 60 first kimometers of the Mamore lower course, which are affected by deforestation, the remaining $175 \mathrm{kms}$ are flowing through dense tropical forest or «terra firme » forest, so called because they are never inundated. This part of Mamore river counts a few meanders intersecting rather straight segments of river. Nonetheless, the mainstream flows within a large alluvial plain, of an average width of $15 \mathrm{kms}$, bordered with steep low banks, showing sedimentary figures, dotted with numerous abandoned meanders and covered in alluvial forests. We have particularly studied in this region, the tributary called Rio Pacaas Novas. The river Pacaas Novas flows within an open water channel of about 100meters wide for almost 30 kilometers from the confluence with the Mamore river. Upstream, its width is less than 100 meters, and it is meandering through an alluvial plain 175kms long, covered with inundated forest about $2 \mathrm{kms}$ wide. It flows within forest and indigene reserves.

The third section is that of the Guapore river. It rises in the heigths of the Parecis plateau, in the State of Mato Grosso, Brazil. From Pontes e Lacerda city, it forms the border with Bolivia, and run along the outcrops of the Guapore shield on 
its rigth bank. Our study begins in Vila Bela da Santíssima Trindade, an old city past capital city of the state. From this point the river is navigable over $1750 \mathrm{kms}$ water course until its confluence with the Mamore river. From Trindade to Pimenteiras, its width is about $300 \mathrm{~m}$ and it is meandering within an alluvial plain from 2.5 to about $7.5 \mathrm{~km}$ wide, covered with inundated forest, surrounded by terra firme forest. From Pimenteiras to Pedras Negras, its floodplain widen until 17 kilometers, bordered with swamps, wetlands, savanas and inundated forest. From Pedras Negras to Principe da Beira, straigth segments are alternating with meandering ones, the alluvial floodplain is wide, reaching $22 \mathrm{kms}$, but well delimited from terra firme covered with forest, with only two tributaries reaching the main course within swamps and wetlands, one on the left bank and one on the right side of the river. At Principe da Beira, a straigth segment cuts into the hills 500 meters high of the Serra Santo Antônio. Twenty three kms after cutting the serra, the river meanders again within its floodplain, very much alike that of the Mamore river above described.

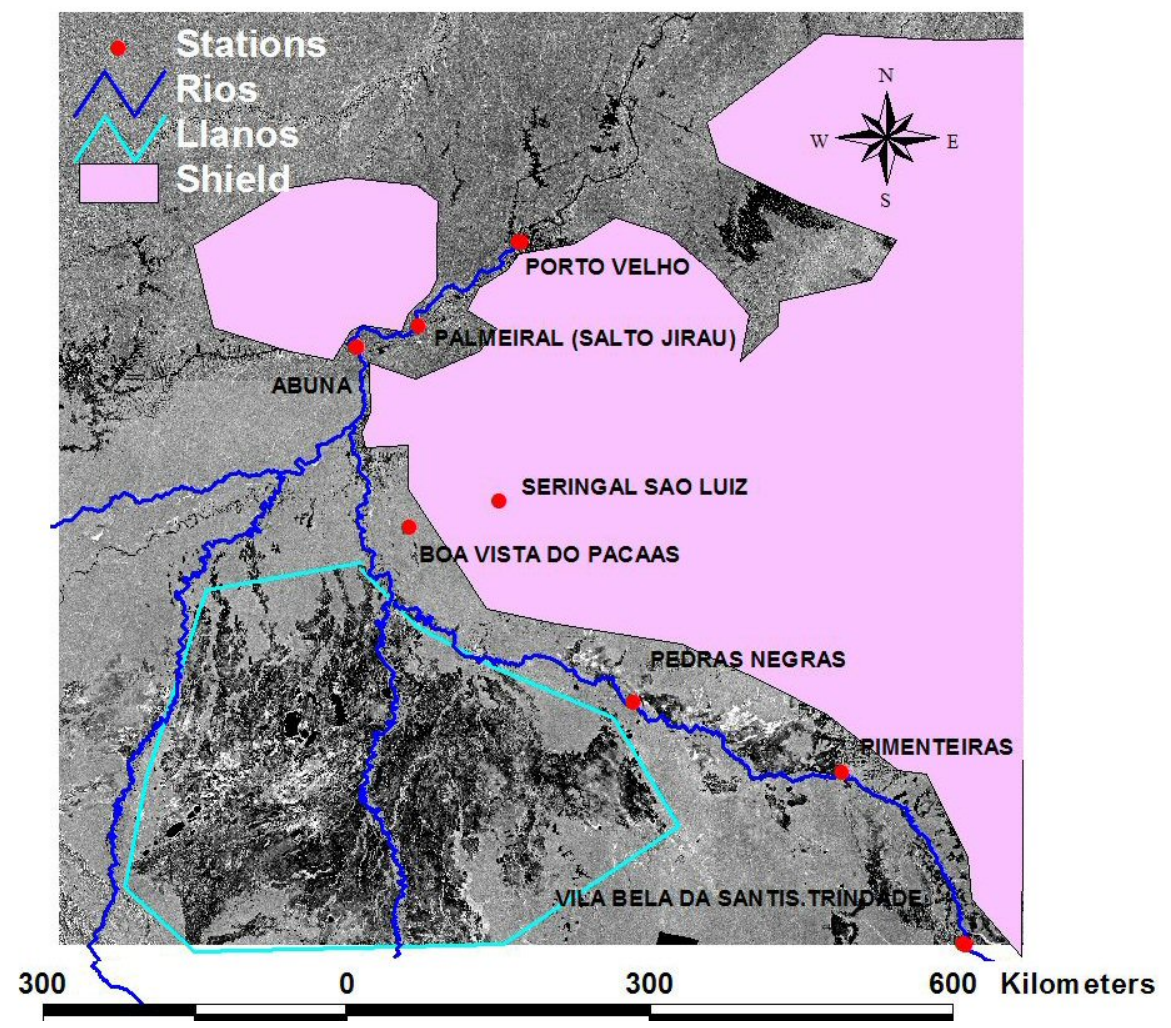

Figure 1 : Situation map drawn over the dry season JERS mosaic

\subsection{Conventional gauge data}

We use the records from all the in situ gauge located along the studied rivers, which had measurements between 2002 and present, i.e. matching the availability of altimetric ENVISAT data. The informations contained within Table 1 have been extracted from the HYBAM site. HYBAM is a French Environment project, which gathers hydrologic data from national agencies, maintains reference gages in key points within the Amazon basin and divulgate all the informations on the internet. The whole set of gages used here are managed by ANA (Agencia Nacional de Aguas), the Brazilian entity in charge of the implementation of the National Water Resources Management system that is regulating water use nationally ${ }^{8}$. For the Amazon basin, only Brazil gives a public access to the hydrological information.

The basin studied area is about $650000 \mathrm{~km}^{2}$. Eight gages were in operation, at least partially, in the time period considered (2002-2008). None of them is levelled to a common altitude reference system. The gage located in Vila Bela da Santissima Trindade is the only one to record a value of elevation. 


\begin{tabular}{|l|l|l|l|l|l|l|}
\hline Gage & Name & River & Latitude $\left(^{\circ}\right)$ & Longitude $\left(^{\circ}\right)$ & Elevation $(\mathrm{m})$ & $\begin{array}{l}\text { Drainage } \\
\text { area }\left(\mathrm{km}^{2}\right)\end{array}$ \\
\hline 15120001 & $\begin{array}{l}\text { VILA BELA DA } \\
\text { SANTIS.TRINDADE }\end{array}$ & Rio Guapore & -15.00810 & -59.94920 & 200 & 18412.0 \\
\hline 15130000 & PIMENTEIRAS & Rio Guapore & -13.48190 & -61.045300 & 0 & 0 \\
\hline 15150000 & PEDRAS NEGRAS & Rio Guapore & -12.85140 & -62.89920 & 0 & 109788.0 \\
\hline 15200000 & $\begin{array}{l}\text { PRINCIPE DA } \\
\text { BEIRA }\end{array}$ & Rio Guapore & -12.42670 & -64.42530 & 0 & 0 \\
\hline 15246000 & $\begin{array}{l}\text { BOA VISTA DO } \\
\text { PACAAS }\end{array}$ & $\begin{array}{l}\text { Rio Pacaas } \\
\text { Novos }\end{array}$ & -11.30000 & -64.88670 & 0 & 5261.0 \\
\hline 15250000 & GUAJARA-MIRIM & Rio Mamore & -10.79250 & -65.34780 & 0 & 589497.0 \\
\hline 15320000 & ABUNA & Rio Madeira & -9.70000 & -65.35000 & 0 & 0.0 \\
\hline 15400000 & PORTO VELHO & Rio Madeira & -8.73667 & -63.92030 & 0 & 55954285.0 \\
\hline
\end{tabular}

Table1 : List of the gages used in this study (from www.mpl.ird.fr/hybam/)

\subsection{Altimetric data}

The radar altimeters embarked on altimetry mission satellites transmit a short microwave pulse in the nadir direction, and the echo reflected by the surface is examined in the time domain. The time span for the pulse to be reflected back to the altimeter corresponds to the distance (or 'range') run by the electromagnetic pulse between the satellite and the earth surface assuming that the pulse is propagating with light celerity. The height $\mathrm{H}$ of the reflecting surface is determined by the difference between the satellite orbit (Alt) and the altimeter range $\mathrm{R}$ measurement, with addition of various corrections taking into account the delays related to the propagation through the atmophere, interaction with the ionopshere and last, correction for liquid and solid tides effects on Earth:

$\mathrm{H}=\mathrm{Alt}-\mathrm{R}+[\mathrm{DTC}+\mathrm{WTC}+\mathrm{IC}+\mathrm{Ts}+\mathrm{Tl}]$

Where DTC is the Dry tropospheric Correction, WTC the Wet troposheric correction, IC the Ionospheric Correction and $\mathrm{Tl}$ and Ts the solid and liquid tide corrections. In Eq (1), $\mathrm{H}$ is considered with respect to a mathematical reference ellipsoid, same as the satellite orbits. A full discussion of the derivation of altimetric heights and their associated errors can be found in Fu and Cazenave ${ }^{9}$.

The altimetric data used in this study come from ENVISAT mission. European Space Agency (ESA) launched ENVISAT on 1 March 2002, in the framework of its Earth observation programme. ENVISAT orbits on a 35-day repeat cycle, with an equatorial ground-track spacing of about $85 \mathrm{~km}$. ENVISAT mission is operating on the same orbit as ERS1 and ERS2. The satellite carries 10 scientific instruments which provide atmosphere, ocean, land, and ice measurements. Its payload includes a radar altimeter, the RA-2 altimeter, a microwave radiometer (MWR), and a tracking system (DORIS), which ensures a very precise orbite determination: an accuracy of around $6 \mathrm{~cm}$ is obtained for the radial component of the satellite direction ${ }^{10}$. RA-2 is a nadir looking pulse limited radar altimeter operating at two frequencies: $13.575 \mathrm{GHz}$ (or $2.3 \mathrm{~cm}$ of wavelength) in Ku-band and $3.2 \mathrm{GHz}$ (or $9.3 \mathrm{~cm}$ ) in S-band ${ }^{11}$. In this study, we use the data that are distributed by the Center of Ocean and Hydrosphere Topography (CTOH) ${ }^{12}$. CTOH is an observation service in charge of maintaining an homegeneous and reliable altimetric database for the long term global monitoring of ocean, lakes, rivers, ice and climate. CTOH distributes MGDR, i.e. the data contained in the Geophysical Data Record (GDR) from ESA, with the addition of some specific ameliorations. For ENVISAT data, they concerns mainly atmospheric and ionospheric corrections. Four types of elevation data (range) are available for the Ku-band, following the type of radar echoes or altimeter waveforms processing (re-tracking) : Ocean, ICE1, ICE2, and SEAICE. Frappart et al., ${ }^{13}$ compared the performances of these retracking algorithms to deliver reliable water levels for land hydrology. Comparisons with in-situ gauge stations showed that Ice-1 algorithm, primarily designed for ice sheets, provided the more robust estimate of water stages for a sample set extracted on rivers and lakes (various locations within the Amazon basin). This algorithm is based on the Offset Centre of Gravity (OCOG) method developed by Wingham et al. ${ }^{14}$ and applied by Bamber ${ }^{15}$ to the ERS-1 and -2 data. This retracking method is a threshold approach. The algorithm calculates the centre of gravity, amplitude, and width of a rectangular box using the maximum of the waveform samples. We used then the range values provided by the ICE1 re-tracking algorithm. 


\subsection{Virtual gauges}

The altimetric data are distributed as they are recorded along the satellite track, ordered by sequencial time orbit cycle. In order to extract the value of water surface elevation, it is necessary to select the data that match exactly the water body under study, i.e. to define "virtual gauges". We use two selection methods described in Roux et al., ${ }^{16}$.

The first one is a semi-automatic method. It consists in extracting the altimetric data that are included into a water body shape. The shape used in this study is issued from a three class segmentation of the JERS-1 SAR high stage mosaic (GRFM mosaic). The 3 classes are : free water (low values of retrodiffusion, due to specular relexion away from the satellite of the incident microwave ${ }^{17}$ ), terra firme forest (intermediate values of retrodiffusion due to L-Band radar scattering within the forest canopy), and flooded forest (bright returns due to corner reflexions between trunks and surface and between branches and surface, ${ }^{18}$ and ${ }^{19}$ ). Only the free water class is used for the extraction of the altimetric data.

The second method is a manual one. Basically, it consists first in a manual geographical extraction of the altimetric data, displayed over an image of the studied region. Second the geographically delimited data are projected into a plan perpendicular to the flow direction. This projection allows a precise delimitation of the data effectively belonging to the water body, as the body surface area can change with time. An example of the selection is given in figure 2 .

The 39 virtual gauges studied are listed in table 2 and 3, and their location is shown in figure 3.

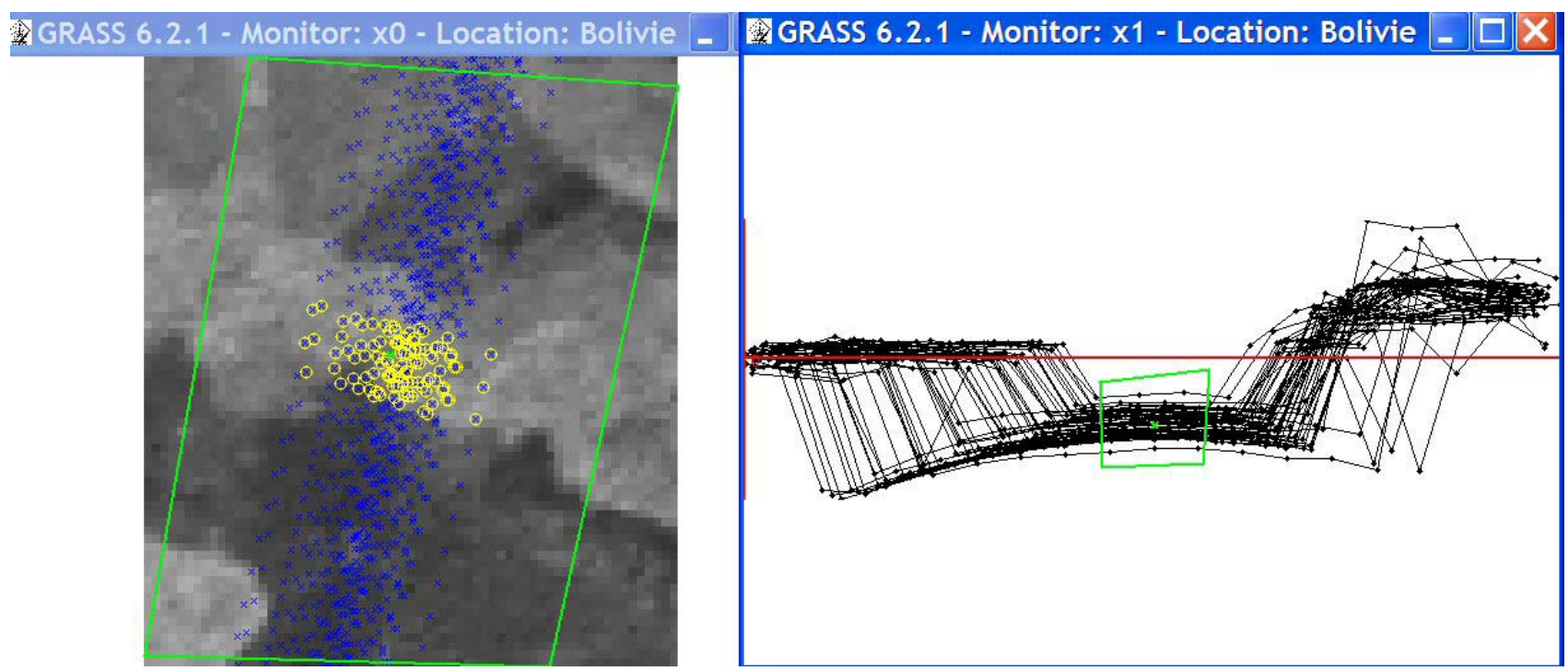

Figure 2 : Manual delimitation of a virtual gauge : example of sv-392 on the Guapore river

\subsection{Time series}

One virtual gauge presents generally several points belonging to the same satellite cycle. In order to retrieve a value for the water body elevation, supposed to be horizontal, two methods have been developped. One calculates the mean and standard deviation of the different measurements for the same cycle/water body, the other one calculates the median and a median dispersion. These two methods are best described in Santos Da Silva et al., ${ }^{20}$. The method allows also to correct the elevation values from an eventual hooking effect. The hooking results of the satellite being locked over a water body before or after having flown above, causing an under-estimation of the elevation (over_estimation of the travel time) ${ }^{13}, 20$ and 21 . Figure 4 presents the example of the virtual gauge sv278-1, affected by a strong hooking effect. Finally, the value of the geoid is added to the elevation value, referenced to the ellipsoid WGS84. The geoid used in this study is GGM02C 22 and 23 . 


\begin{tabular}{|c|c|c|c|c|c|c|}
\hline $\begin{array}{l}\text { Virtual } \\
\text { gauge }\end{array}$ & $\begin{array}{l}\text { ENVISAT } \\
\text { Track }\end{array}$ & River & $\begin{array}{l}\text { Mean } \\
\text { latitude }\left(^{\circ}\right)\end{array}$ & $\begin{array}{l}\text { Mean } \\
\text { longitude }\left(^{\circ}\right)\end{array}$ & $\begin{array}{l}\text { Elevation } \\
\text { mean }(\mathrm{m})\end{array}$ & $\begin{array}{l}\text { Mean } \\
\text { Standard } \\
\text { deviation }\end{array}$ \\
\hline sv951-1 & 951 & Madeira & -8.84196 & -64.0225 & 55.2 & 0.25 \\
\hline sv736-1 & 736 & Madeira & -9.29482 & -64.3983 & 66.4 & 0.02 \\
\hline sv493-1 & 493 & Madeira & -9.25 & -64.6401 & 82.6 & 0.46 \\
\hline sv278-1 & 278 & Madeira & -9.547 & -65.19 & 84.8 & 1.89 \\
\hline sv035-1 & 035 & Madeira & -9.51419 & -65.3088 & 85.2 & 0.10 \\
\hline sv278-2 & 278 & Madeira & -9.87 & -65.28 & 111.3 & 0.19 \\
\hline sv278-3 & 278 & $\begin{array}{l}\text { Confluence } \\
\text { Madeira-Mamore }\end{array}$ & & & 127.3 & 0.98 \\
\hline sv736-3 & 736 & $\begin{array}{l}\text { Confluence } \\
\text { Mamore-Guapore }\end{array}$ & -11.9519 & -65.0166 & 126.1 & 0.84 \\
\hline sv035-2 & 035 & Guapore & -12.1222 & -64.721 & 126.45 & 1.23 \\
\hline sv192 & 192 & Guapore & -12.4585 & -64.4127 & 128.4 & 0.84 \\
\hline sv493-2 & 493 & Guapore & -12.5026 & -63.9158 & 132.3 & 0.20 \\
\hline sv650 & 650 & Guapore & -12.4458 & -63.6914 & 133.9 & 0.04 \\
\hline sv951-2 & 951 & Guapore & -12.6298 & -63.1691 & 137.9 & 0.09 \\
\hline sv106 & 106 & Guapore & -12.7431 & -63.0404 & 139.9 & 0.08 \\
\hline sv564 & 564 & Guapore & -13.118 & -62.407 & 147.0 & 0.10 \\
\hline sv407 & 407 & Guapore & -13.076 & -62.3483 & 147.8 & 0.15 \\
\hline sv020 & 020 & Guapore & -13.5747 & -61.7929 & 156.2 & 0.25 \\
\hline sv865 & 865 & Guapore & -13.52 & -61.5263 & 160.5 & 0.12 \\
\hline sv478 & 478 & Guapore & -13.5059 & -61.0586 & 166.2 & 0.15 \\
\hline sv936 & 936 & Guapore & -13.9369 & -60.4389 & 178.1 & 0.20 \\
\hline sv392 & 392 & Guapore & -14.8771 & -59.9365 & 194.3 & 0.01 \\
\hline sv779 & 779 & Guapore & -14.9733 & -59.758 & 204.6 & 0.06 \\
\hline sv493-3 & 493 & Pacaas Novas & -11.2074 & -64.2093 & 144.7 & 0 \\
\hline sv736-2 & 736 & Pacaas Novas & -11.1943 & -64.8452 & 125.0 & 0.16 \\
\hline sv035-3 & 035 & Pacaas Novas & -11.2204 & -64.925 & 123.9 & 0.14 \\
\hline
\end{tabular}

Table2 : List of virtual gauges on rivers

\begin{tabular}{|l|l|l|l|l|l|l|}
\hline $\begin{array}{l}\text { Virtual } \\
\text { gauge }\end{array}$ & $\begin{array}{l}\text { ENVISAT } \\
\text { Track }\end{array}$ & Basin & $\begin{array}{l}\text { Mean } \\
\text { latitude }\left(^{\circ}\right)\end{array}$ & $\begin{array}{l}\text { Mean } \\
\left.\text { longitude }{ }^{\circ}\right)\end{array}$ & $\begin{array}{l}\text { Elevation } \\
\text { mean (m) }\end{array}$ & $\begin{array}{l}\text { Mean } \\
\text { Standard } \\
\text { deviation }\end{array}$ \\
\hline sv020-lac1 & 020 & Guapore & -13.0308 & -61.6688 & 163.7 & 0.08 \\
\hline sv106-lac4 & 106 & Guapore & -12.9604 & -63.0898 & 140.6 & 0.03 \\
\hline sv106-lac5 & 106 & Guapore & -13.0782 & -63.1168 & 139.9 & 0.02 \\
\hline sv407-lac1 & 407 & Guapore & -12.963 & -62.374 & 152.0 & 0.10 \\
\hline sv564-lac1 & 564 & Guapore & -12.9673 & -62.3727 & 152.0 & 0.12 \\
\hline $\begin{array}{l}\text { sv650- } \\
\text { inond }\end{array}$ & 650 & Guapore & -12.5824 & -63.7224 & 133.5 & 0.26 \\
\hline sv865-lac1 & 865 & & & & & 164.7 \\
\hline sv865-lac2 & 865 & Guapore & -13.0373 & -66.6389 & 161.3 & 0.06 \\
\hline sv951-aff & 951 & Guapore & -13.6146 & -66.507 & 140.2 & 0.06 \\
\hline sv951-lac1 & 951 & Guapore & -12.8533 & -63.1182 & 143.1 & 0.56 \\
\hline sv951-lac2 & 951 & Guapore & -12.2975 & -63.2447 & 141.0 & 0.05 \\
\hline sv951-lac3 & 951 & Guapore & -12.4829 & -63.2024 & 139.8 & 0 \\
\hline sv951-lac4 & 951 & Guapore & -12.7481 & -63.1417 & 140.6 & 0.06 \\
\hline sv951-lac5 & 951 & Guapore & -12.9691 & -63.0921 & 141.1 & 0 \\
\hline
\end{tabular}

Table 3 : List of virtual gauges on lakes, wetlands and floodplain 


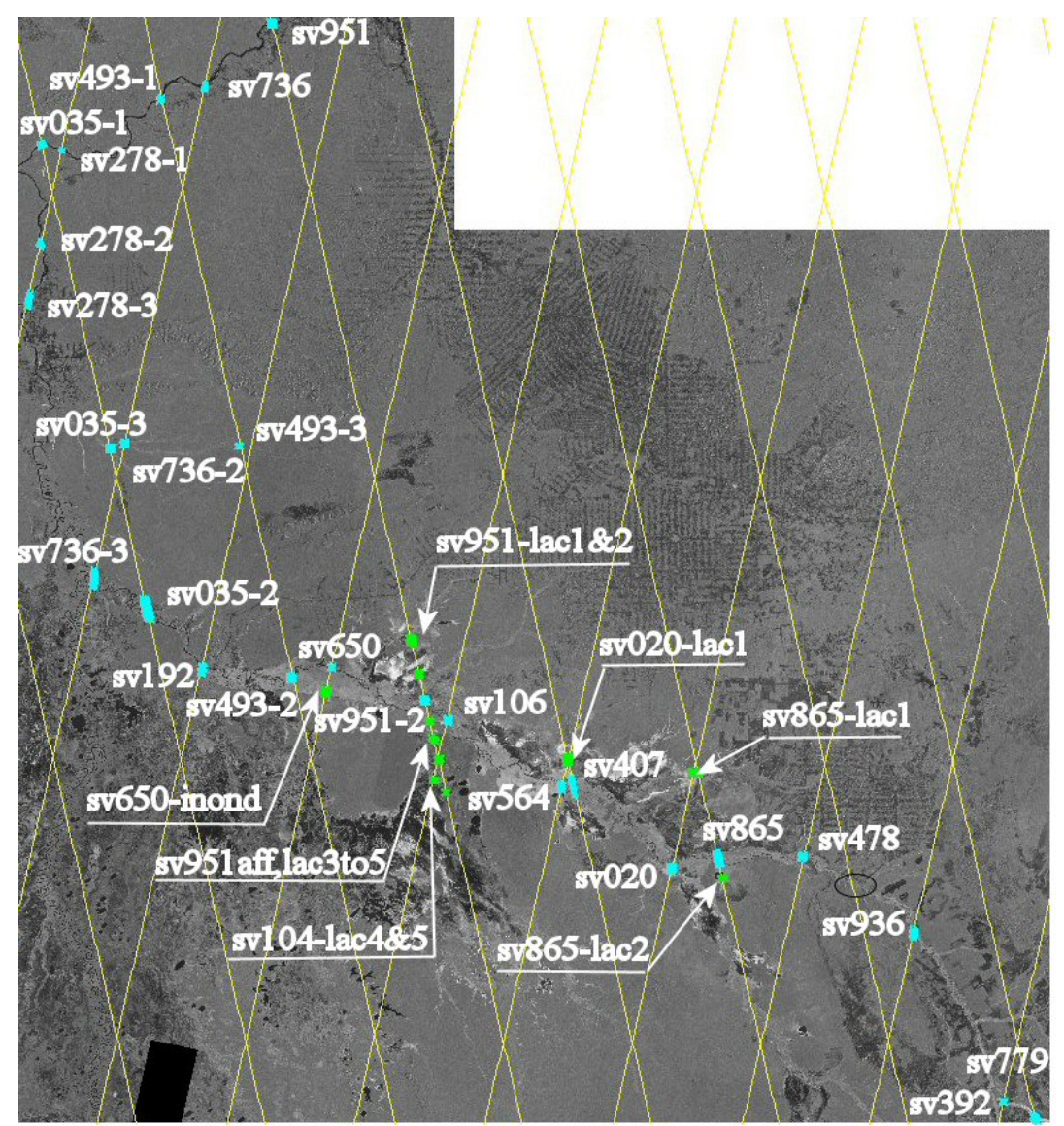

Figure 3 : Situation map of the virtual gauges on rivers (cyan), lakes, wetlands and floodplains (green)
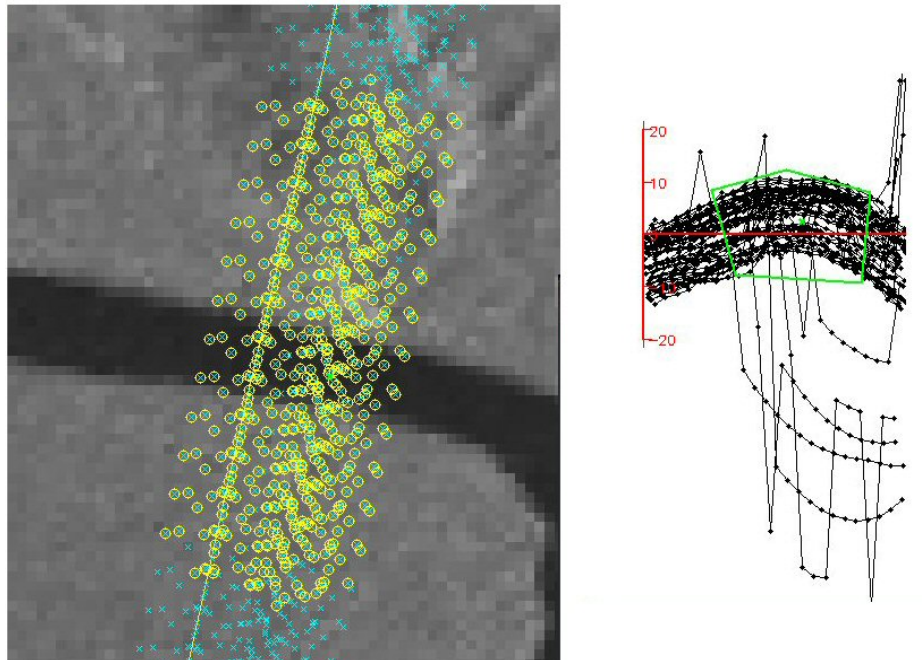

Figure 4 : Hooking effect : example of the virtual gauge sv278-1

\subsection{Validation of the virtual gauges}

We use two ways for validating the time series determined at virtual gauge. The first one was comparing time series at virtual gauge with time series obtained at conventional limnimetric gauges (figure 5). The second one was comparing two altimetric time series obtained at a two-tracks crossing (figure 5, last two figures). 


\subsection{Slope determination}

Elevation profile has been determined for Madeira, Guapore, and Pacaas Novas rivers, for low stage and high stage. Water stage has been extracted from the altimetric time series, and the distance between the virtual gages has been measured on the JERS-1 image.

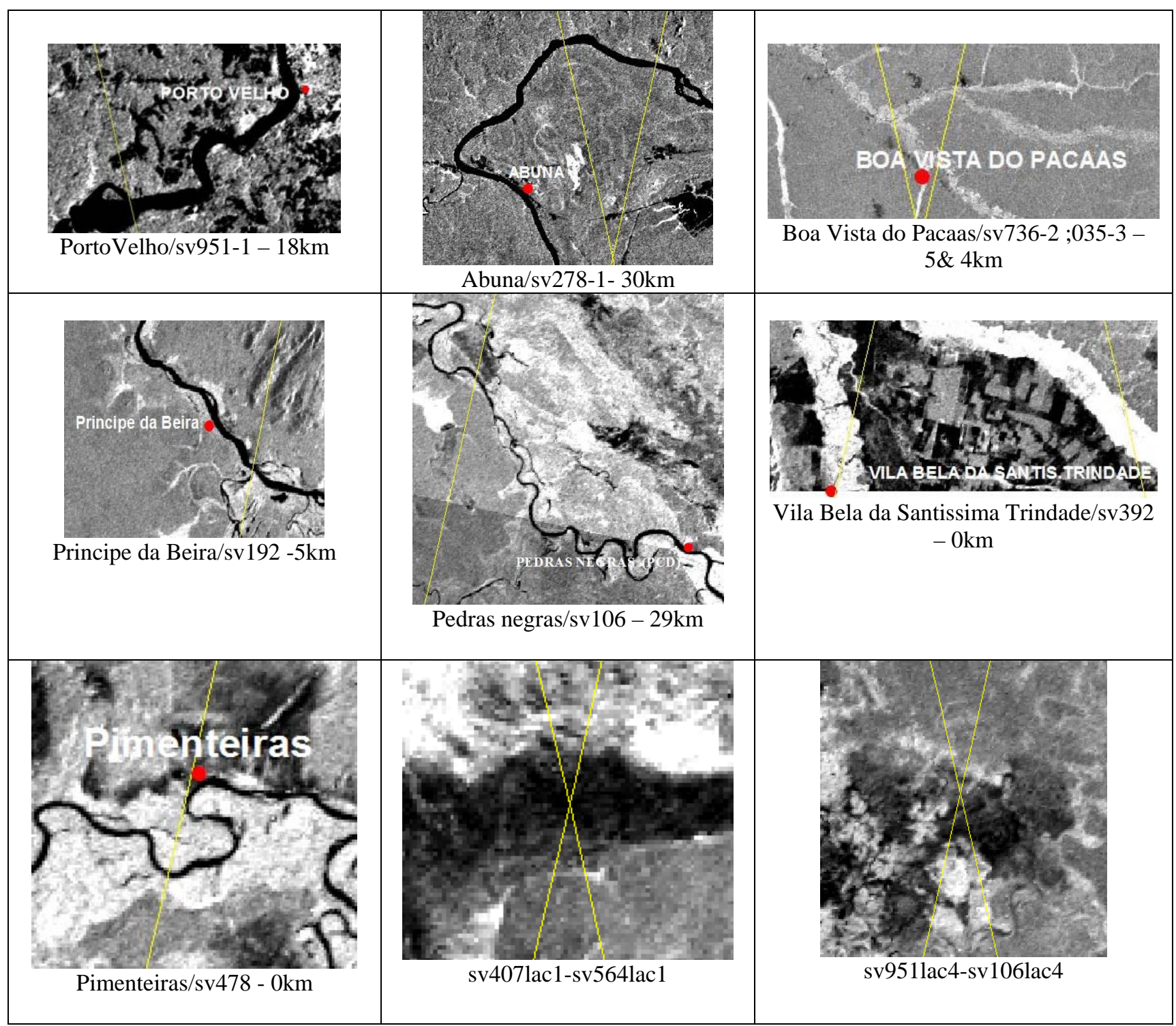

Figure 5 : Sites of comparison between conventional and virtual gauges; in kilometers the distance between the two gauges ; two last figures : Sites of track-crossing over lakes

\section{RESULTS AND DISCUSSION}

\subsection{Validation of the virtual gauges}

The time series of conventional and virtual gauges as well as the cross-tracking situations are presented figure 6. All Y axis for the times series are in meters. For the comparison between conventional and virtual gauges, the conventional gauge time serie has been linearly shifted from the mean difference between the two series. This simple procedure allows an almost perfect fit beween the two series for Porto Velho, Pedras Negras, Pimenteiras and Boa Vista dos Pacaas. The 
lack of temporal resolution of the altimetric time series (35 jours between two cycles) does not allow to follow the hydrological events that are monitored by the daily conventional times series, the better example being Porto Velho. In
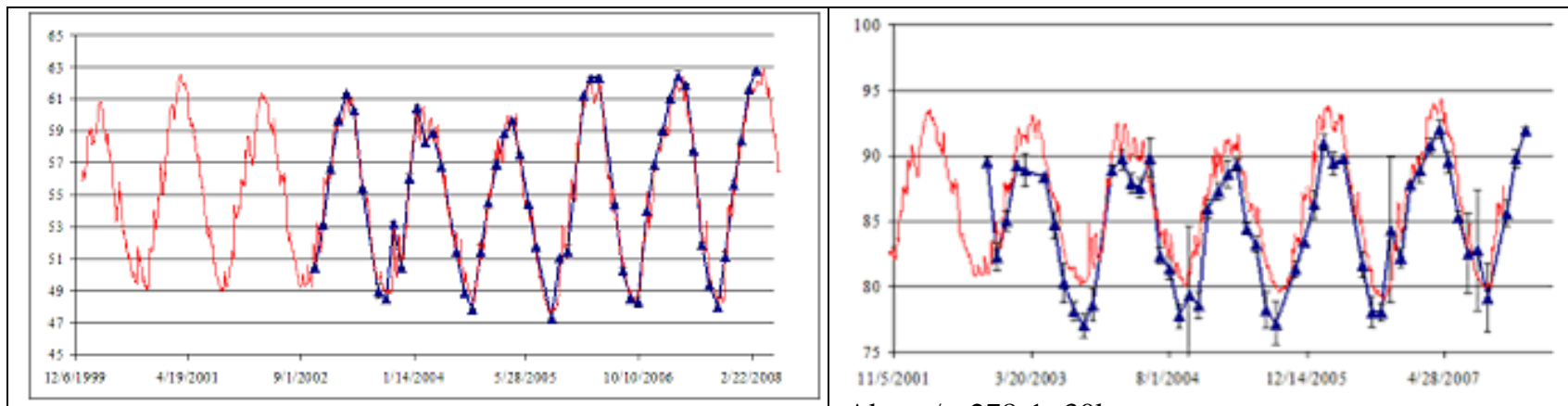

PortoVelho/sv951-1 - 18km

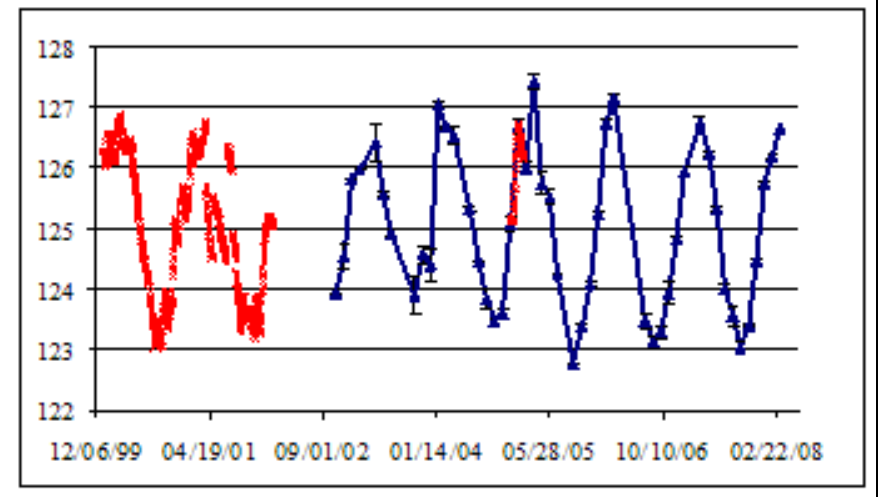

Abuna/sv278-1- 30km
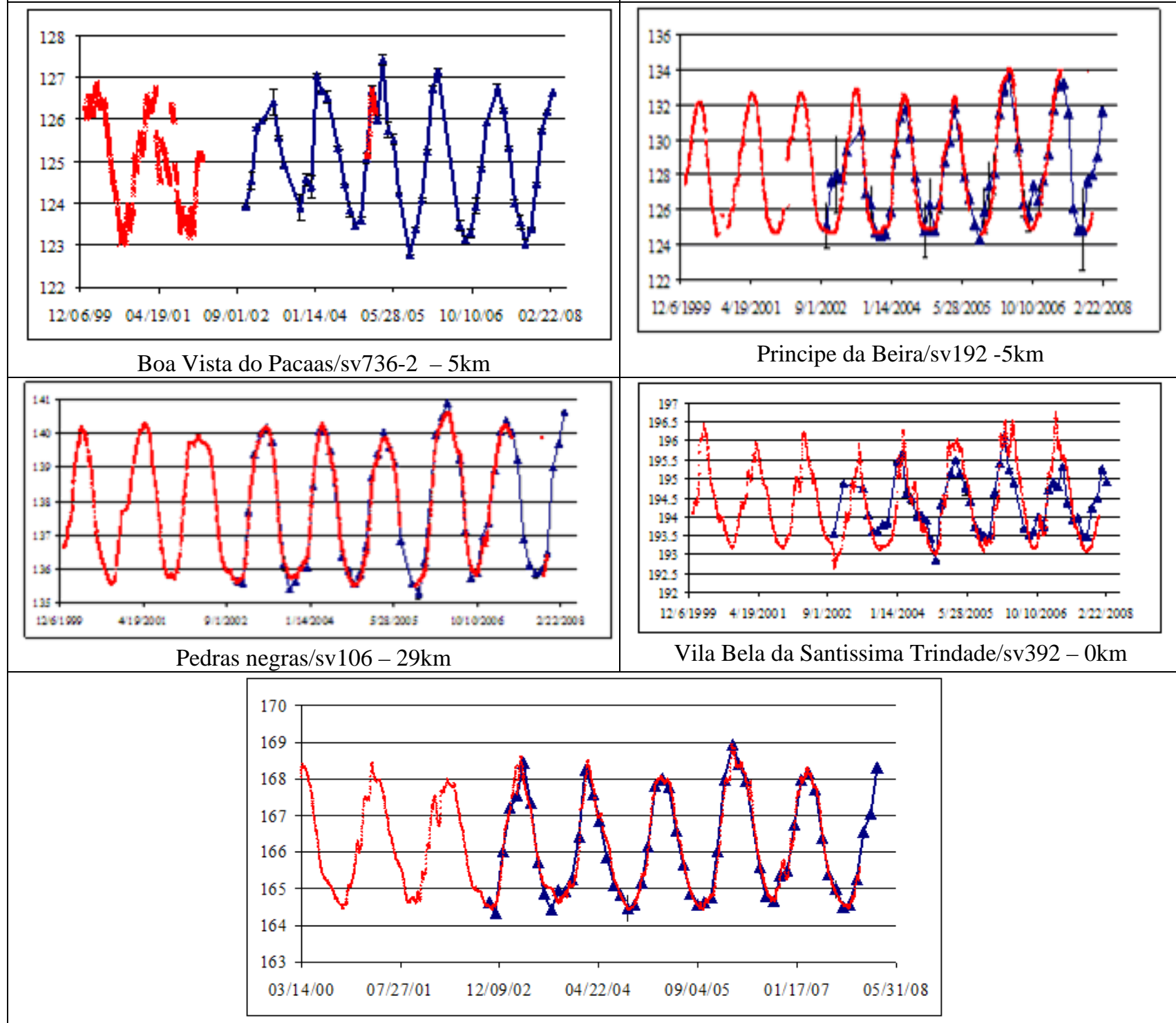

Pimenteiras/sv478 - 0km

Figure 6 : comparison between conventional gauges (red) and virtual gauges (blue). 
the case of Pedras Negras, the altimetric time serie has a tendency to overestimate flood and underestimate low stage, but the simple matching of the mean could be responsible of that effect for two sites distant of $29 \mathrm{~km}$. The river section is almost the same (about 250m width) at the two sites, but there is a tributary joining the Guapore between Pedras Negras and sv 106 (figure 5). The gauge station of Boa Vista dos Pacaas have been interrupted at the end of 2001, but two months records at the beginning of 2005 allow to evidence the perfect match of the data. At the site of Boa Vista, the open water is less than 100 meters width as it is not possible to see it on JERS-1 images, where it appears that the main stream of the river is covered with trees, and it seems that it is the flooded forest that gave a sufficient energetic return to the altimeter for a waveform to be successfully analysed. The conventional gauge station not being levelled, it is impossible to assess the precision of the absolute altitude. But the hydrological cycles of the river at that site seem to be correctly monitored.

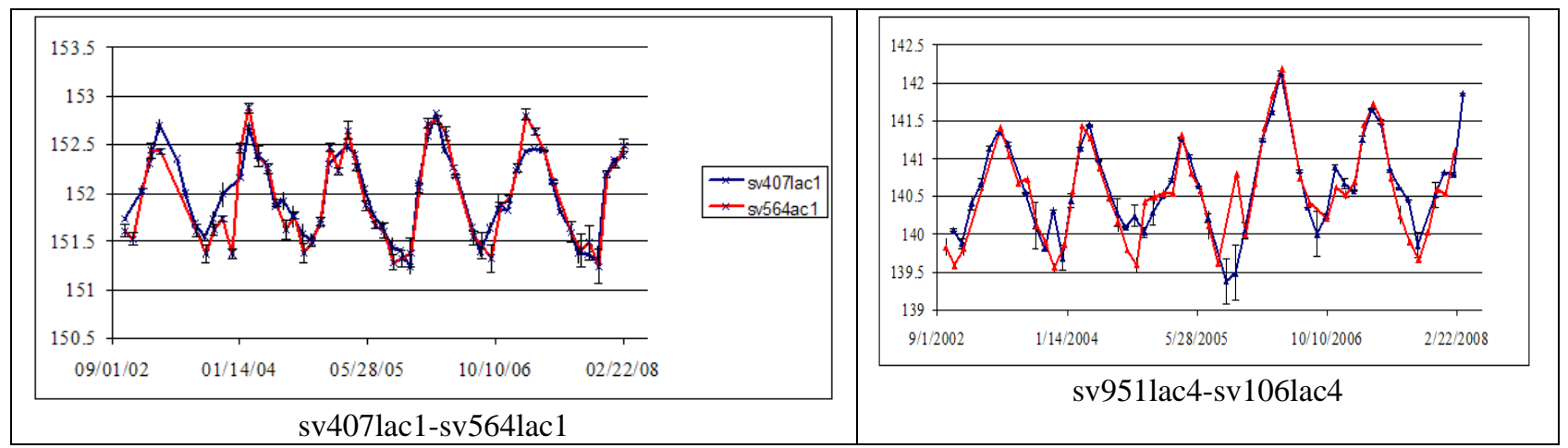

Figure 7 : Cross-tracking situations

The other comparisons between conventional and virtual gauges are registering a mismatch between the two series. Although the seasonal hydrological variations are roughly the same, they are different kinds of differences : For Abuna, the shifting of the conventional serie has matched the rising and falling stage, but both flood and low stage have been underestimated by the altimetric data. In the case of Principe da Beira, some precursor events to the flood that have been registered in the altimetric time serie do not appear in the daily stage of the conventional record. All points of these early events are showing high dispersion of the median. For the Vila Bela of Santissima Trindade time serie, there is a sligth dephasage of the two series, the altimetric flood rising anf falling sooner than the conventional recorded one. The distance between the gauges can be no explanation of these mismatches. For the Vila Bela situation, the explanation could be that the conventional gauge is registering the water stage on the main channel of the river, while the altimetric virtual gauge is measuring the water surface elevation on a transect of about 6 kilometers long, mostly over flooded forest. But the situation is almost the same in Pimenteiras. So, the floodplain could be closely connected to the river stage, contrary to the upstream situation of Vila Bela. In the Principe da Beira case, the altimetric gauge is following for $6 \mathrm{~km}$ a small tributary before crossing the main stream. This stream could be responsible for the early events registered in the altimetric time serie. Several tributaries are joining in Madeira between Abuna and sv278-1. Otherwise the width of the river is nearly the same, and there is no evidence of a floodplain. It seems nonetheless that a network of flooded forest is cross-cutting the large bend of the Madeira river between Abuna and downstream sv278-1. Both the joining in of the tributaries and the flowing off of a part of the flow could be reponsible for the mismatch.

For the two cross-track situation, there had none adjustment between the two time series. The two examples demonstrate no systematic bias between the two tracks, and a fairly good match for a maximum difference of 2 meters between high and low stage.

\subsection{Leveling of the in situ gauges}

The method used to level the conventional gauge is a crude one, as it consists in matching the means of the two series, the linear shift of the in situ gauge being retained as the level of the zero gauge. The results are summarized in table 4. Some GPS campaigns have been carried out with the objective of levelling the gauges of the Amazon main tributaries. Some of the results of these campaigns are reported in Kosuth et al., ${ }^{24}$, as well as results of levelling obtained with Topex Poseidon (T/P) data. The results reported by Kosuth et al., are given referenced to the ellipsoid WGS84 and geoid 
EGM96. The difference in geoid can account as to $0.50 \mathrm{~m}$ and up to $1 \mathrm{~m}$ difference between the values obtained. For example, in Porto Velho, the difference between the two geoids is of of $56 \mathrm{~cm}$. The standard deviation of the two series of measurements is of $1.80 \mathrm{~m}$. The uncertainty of the altimetric levelling is therefore high, of the order of $2 \mathrm{~m}$, but considering the rough method used, which could be greatly refined, and the difficulty and the cost of the field campaigns involved in a ground levelling of the whole Amazonian network, it is worth trying to use altimetric data for a first approximation of global levelling.

\begin{tabular}{|l|c|c|c|}
\hline Gauge & Altitude $(\mathrm{m})$ - ENVISAT & Altitude (m) GPS ${ }^{24}$ & ${\text { Altitude }(\mathrm{m}) \mathrm{T} / \mathrm{P}^{24}}^{24}$ \\
\hline Porto Velho & 45.94 & 43.28 & 73.16 \\
\hline Abuna & 73.69 & & 120.81 \\
\hline Guaraja-Mirim & 118.0 & & 121.69 \\
\hline Boa Vista dos Pacaas & 120.0 & & 135.92 \\
\hline Principe da Beira & 120.9 & & 161.36 \\
\hline Pedras Negras & 133.25 & & 191.66 \\
\hline Pimenteiras & 161.47 & & \\
\hline $\begin{array}{l}\text { Vila Bela da Santissima } \\
\text { Trindade }\end{array}$ & 194.34 & & \\
\hline
\end{tabular}

Table 4 : Conventional gauge levelling by ENVISAT RA2 and comparison with previous study ${ }^{24}$

\subsection{Comparison of methods}

Only one virtual gauge could not be created, with either the automatic method or the manual one. It concerns the track 321 crossing the Guapore river at $-13.65^{\circ}$ latitude and $-60.78^{\circ}$ longitude. Track 321 is ascending and before crossing the river, it flies over an outcrop of the serra Ricardo Franco falling abruptly from $500 \mathrm{~m}$ to the level of the river. In this situation (figure 8), the altimeter could not lock on the river level.

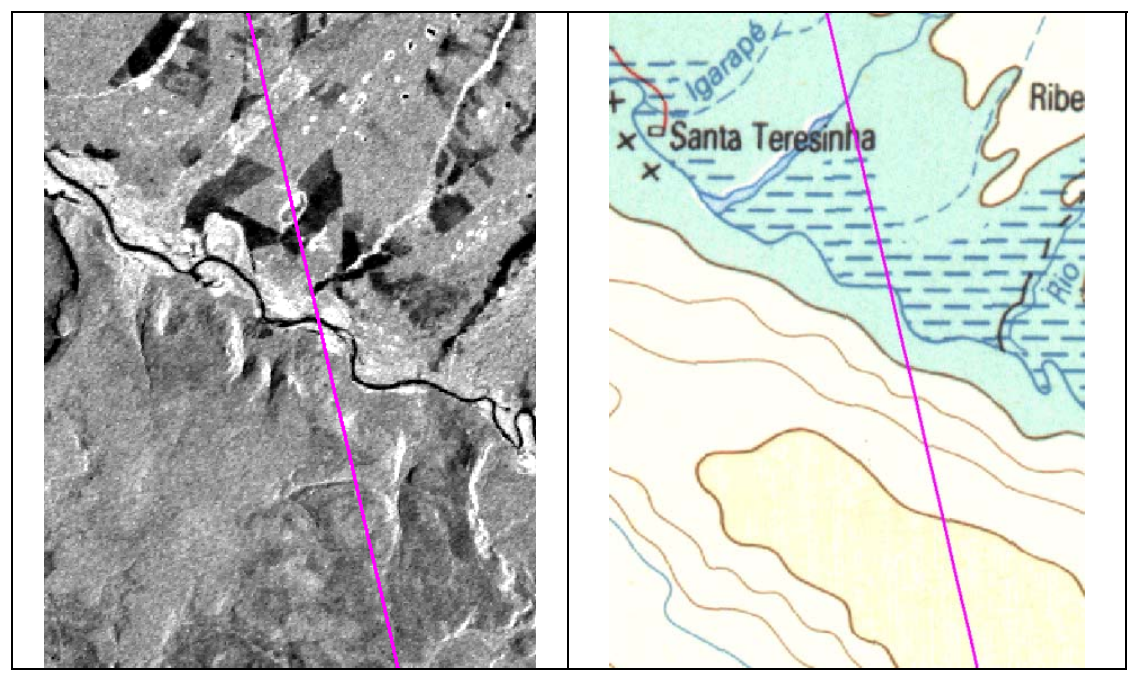

Figure 8 : Situation of the river crossing by the ENVISAT track 321 (pink line)

Three virtual gauges could not be obtained by the manual method : sv493-1, 278-2 and 278-3 (figure 9). In the first situation, that of sv493, the track is crossing the river in great part over an island, and in the middle of a river waterfall known as the Salto Jirau. The conventional gauge of Palmeiral nearby has no record of stage, it is why it has not be used in the comparison between conventional and virtual gauge. The other two situations are characterized by the crossing of the river in a direction nearly parallel to the river flow. The two possible explanations are 1. longitudinal slope and 2. inadequate projection of the data in the direction perpendicular to the flow, which is the method used in the manual selection of virtual gauge. These situations represent the worst cases for retrieving of altimetric virtual gauges : for the three virtual gauges, the respective standard deviations of the time serie were $: 0.46 \mathrm{~m}, 0.18 \mathrm{~m}$ and 0.98 , with very few points per cycle, some cycles above $2 \mathrm{~m}$ of standard deviation, and a lot of missing date. 
In all other situations, manual extraction has been performed, with results slightly better (lower standard deviation and more cycles sampled) than the automatic one. The automatic extraction has been found to be more reproductible, and not statistically different than the manual one ${ }^{16}$. The reproductibility criteria is certainly best fulfilled by the automatic method, but it seems that in the cases where the river is mostly perpendicular to the flow direction, with small width, and extensive floodplain, the manual extraction can be the best method to employ.

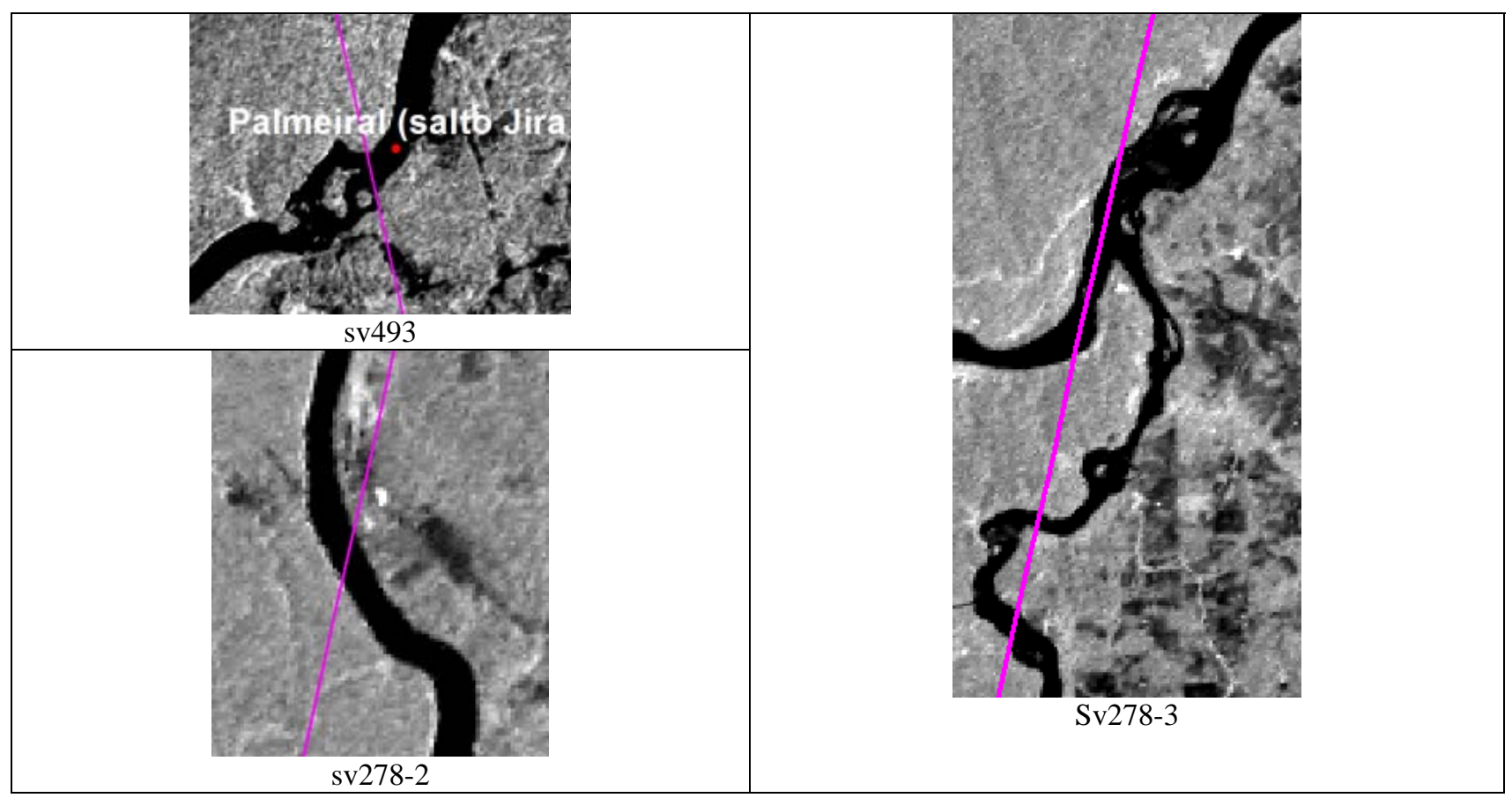

Figure 9 : Site configurations of the virtual gauges sv 493, sv278-2, and sv278-3

To illustrate the difference between the methods of extraction, figure 10 shows the crossing of the Guapore river by the track 035. This is another rough situation for the altimetric data to give good results. The river is forming elongated meanders in a direction quasi-longitudinal to the track direction. The mean standard deviation of the time serie is $1.23 \mathrm{~m}$.

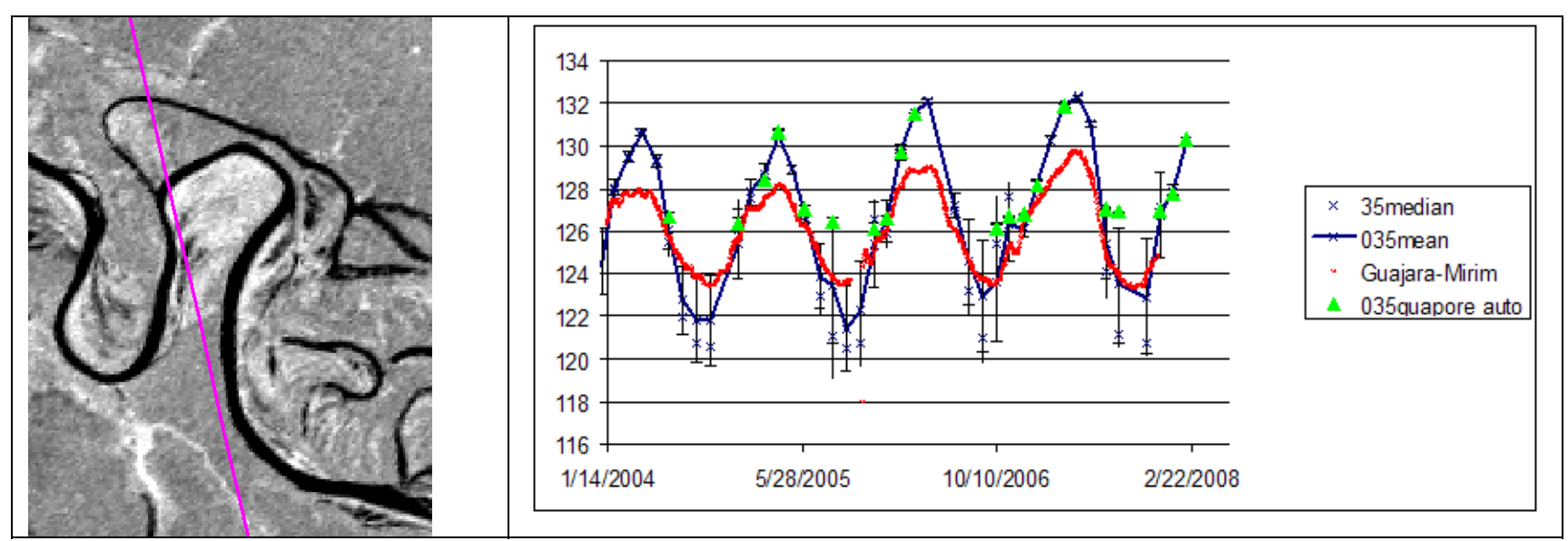

Figure 10 : sv035-2 location and associated time serie

The conventional gauge of Guajara-Mirim, although being located 274km downstream of the virtual gauge, gives some insight on the different extraction method. All three methods have given more or less the same results at high stage, with many missing cycles for the automatic method; the errors are great at low stage for the manual method, certainly because of the floodplain being dry at this time, but the automatic method is missing completely the low water stage. 
As for the correction of the hooking effect, it seems efficient in the case of narrow rivers without associated floodplain, as it is the case for the virtual gauge 278-1 (figure 4). The time series obtained respectively without and with hooking correction for this virtual gauge are shown figure 11.

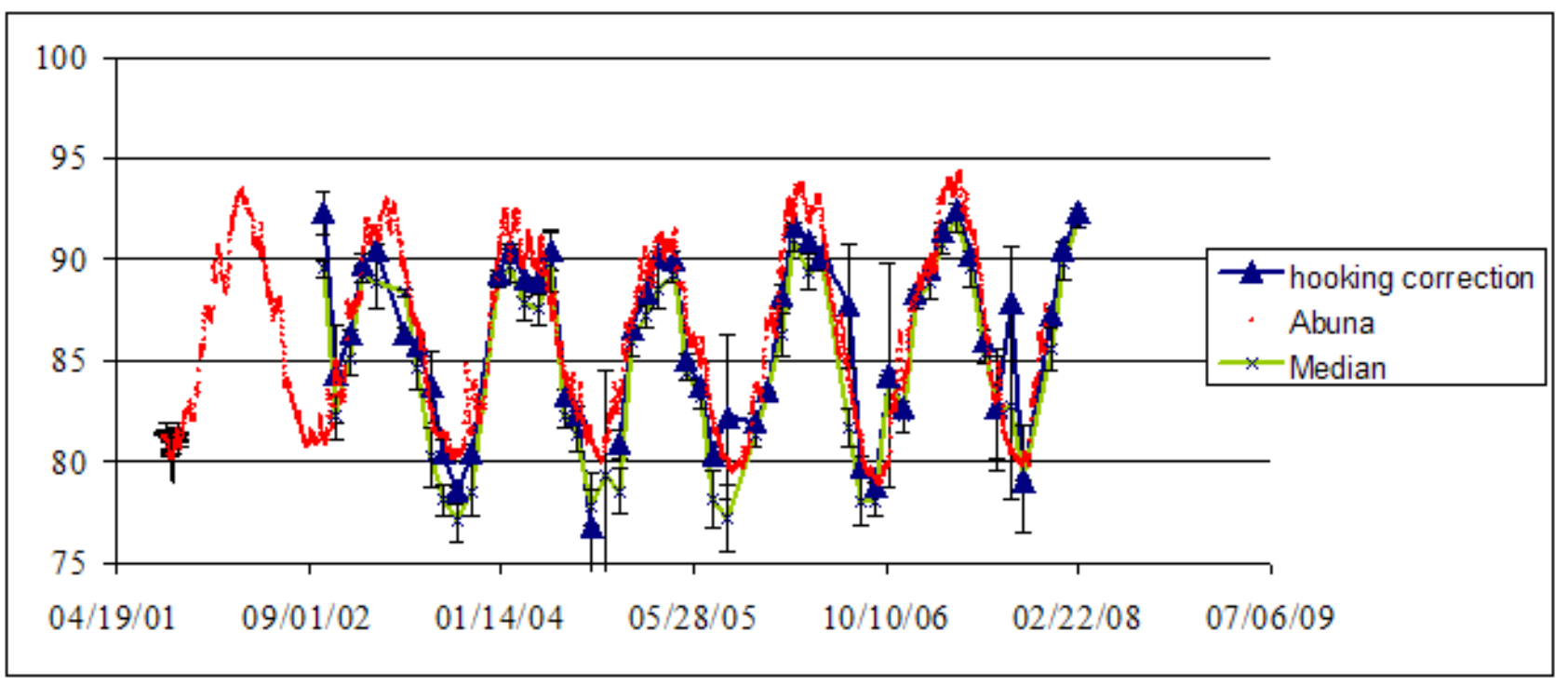

Figure 11 : Effect of the hooking correction on the time serie calculation

\subsection{Relationship between the river, the floodplain and the watershed}

Table 3 lists the virtual gauges created on lakes, swamps and floodplain. Some, where two tracks were crossing over, have allowed a validation of the time series obtained. We will give two examples of relationship retrieved by altimetry :

a. Between the river and its floodplain



Figure 12 : sv650 comparison between mainstream and floodplain 
Figure 12 illustrates how altimetric data can retrieve the relationship between the river and its floodplain. Left is the image of the site (JERS-1, high stage mosaic). The track 650 crosses the Guapore river (black) and its floodplain covered by inundated forest (bright radar return) from North $(\mathrm{N})$ to South $(\mathrm{S})$. The upper part of the figure represents the transect of ENVISAT data in a vertical plane along the track. From North $(\mathrm{N})$ to South $(\mathrm{S})$, the altimeter locks on the river before arriving on it, and crosses the river with a first hooking effect (apex at the first arrow from the right). Crossing the entire floodplain, the elevation remains flat during a great part of the high stage. The altimeter locks three more times at intermediate elevations and only two more times after the river for low stages. The maximum stage difference is at the apex of the river. The two arrows at the left are signaling two derivations of the river that are permanently inundated (narrow sinuous black lines at the South of the floodplain. The time series displayed at the bottom right of the figure are extracted at the two extremity of the floodplain (right arrow = river named mainstream on the time serie; left arrow $=$ South derivation named floodplain on the time serie). 50 to 70 centimeters of water stage difference are observed between the two water bodies. The seasonal water cycle is well phased, but it can be observed that the inundation plain is rising after and decreasing before the river.

\section{b. Between the river, swamps and lakes within the watershed}

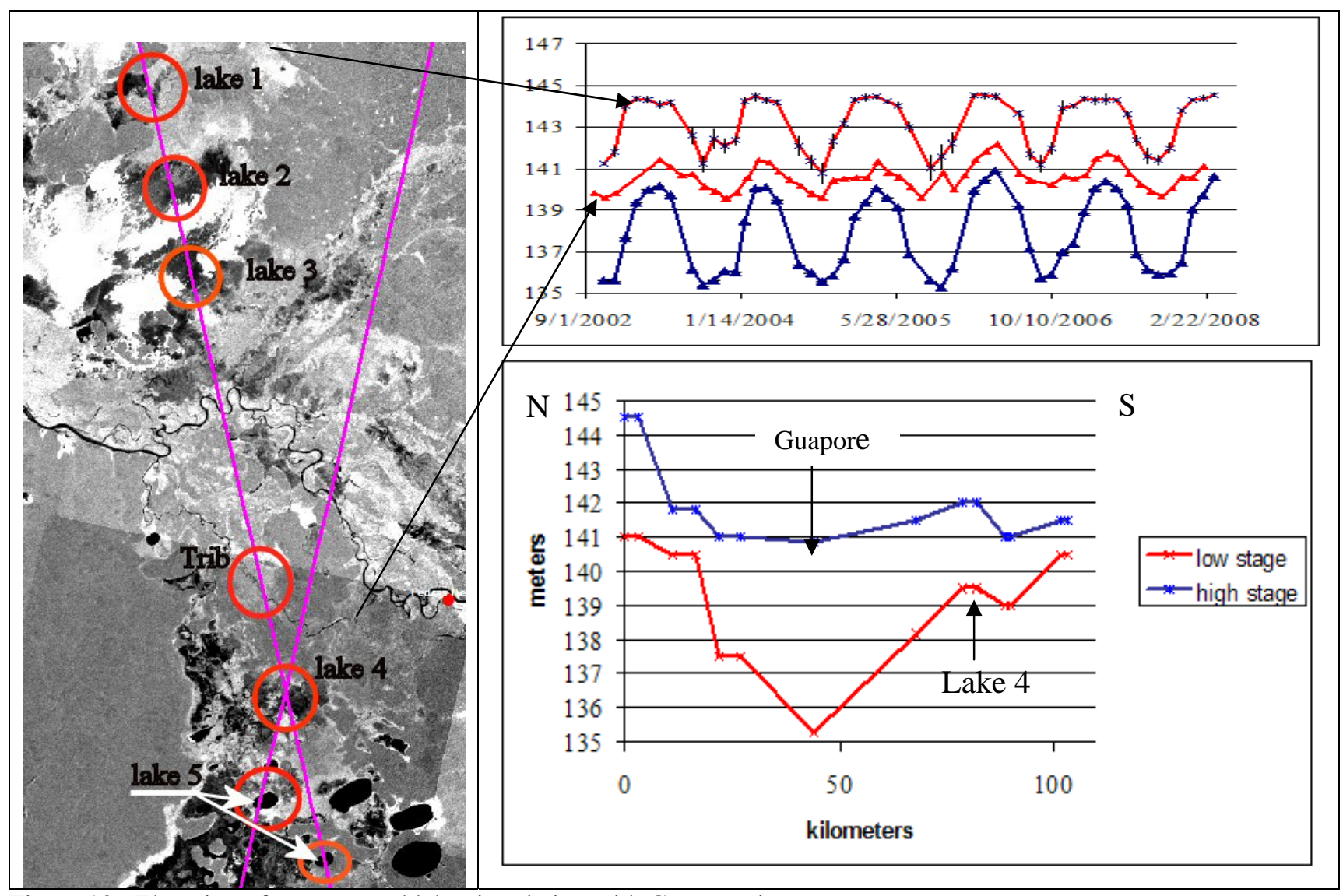

Figure 13 : Elevation of swamps and lakes in relation with Guapore river water stage

The different swamps and lakes observed by altimetry are located at the left of the figure 13. At bottom right, are represented the respective stages at low and high flow of the water bodies. And at the top right, the time series of lake 1 and lake 4 in relation with the Guapore river. First, the two rounded-shaped lake 5 at the South of the image seem to be unconnected with the alluvial water-table of the Guapore river. Contrary to the alluvial floodplain case seen above, the lakes 1 and 4 stages are increasing before and decreasing after the river stage. These observations could indicate that at this location, the river is fed by the watershed swamps, probably mainly by those located on the right bank as they have a greater extent than those located on the right and almost the same amplitude of stage variation as the main stream. 


\subsection{Rivers elevation profile}

On figure 14 is plotted the whole set of altimetric time series that has been registered on the Guapore river by the ENVISAT altimeter. The elevation profile on figure 15 has been computed from these time series for the Guapore part. The same procedure has been used to plot the Madeira and Mamore parts. The water profile of the Madeira river is much steeper than the profile of the Mamore-Guapore system

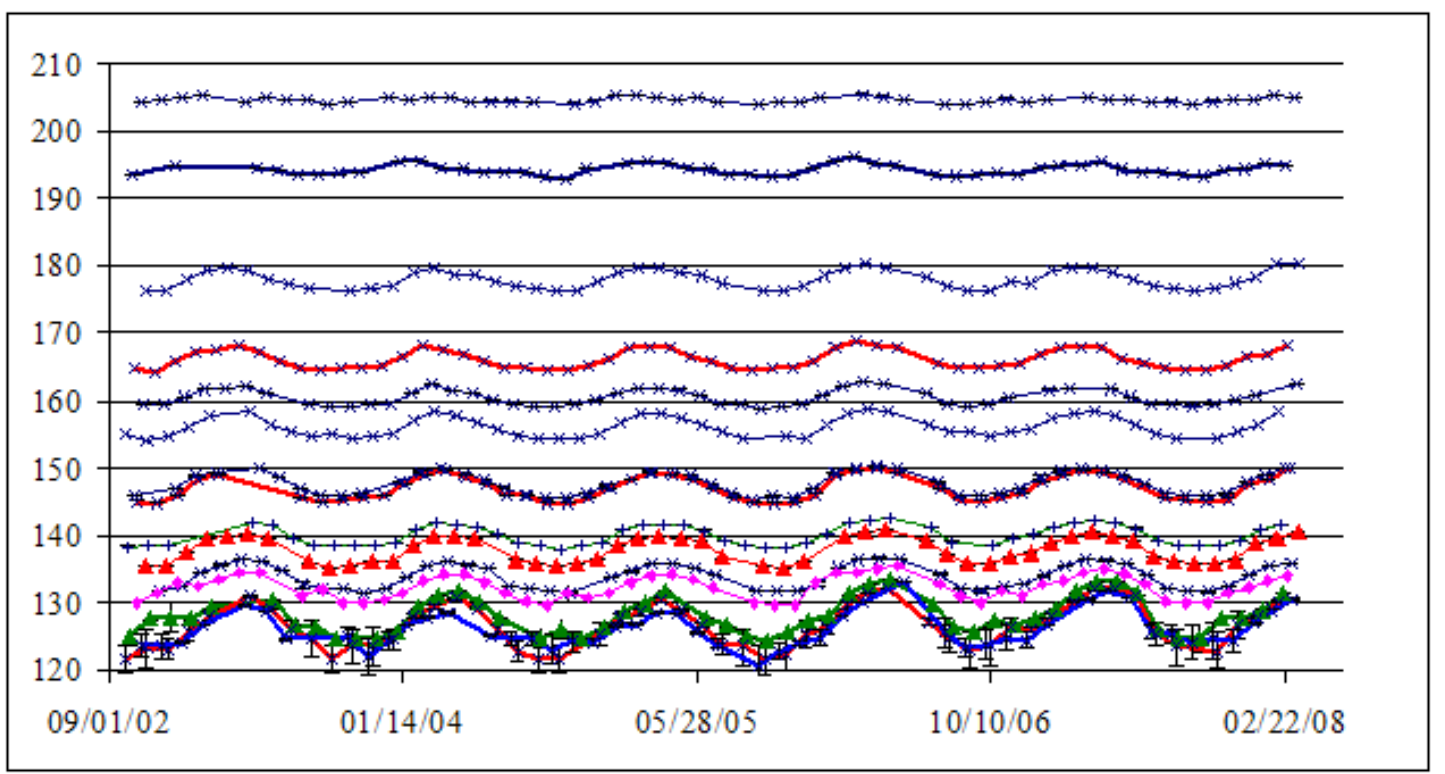

Figure 14 : Altimetric time series used to calculate the water elevation profile of the Guapore river

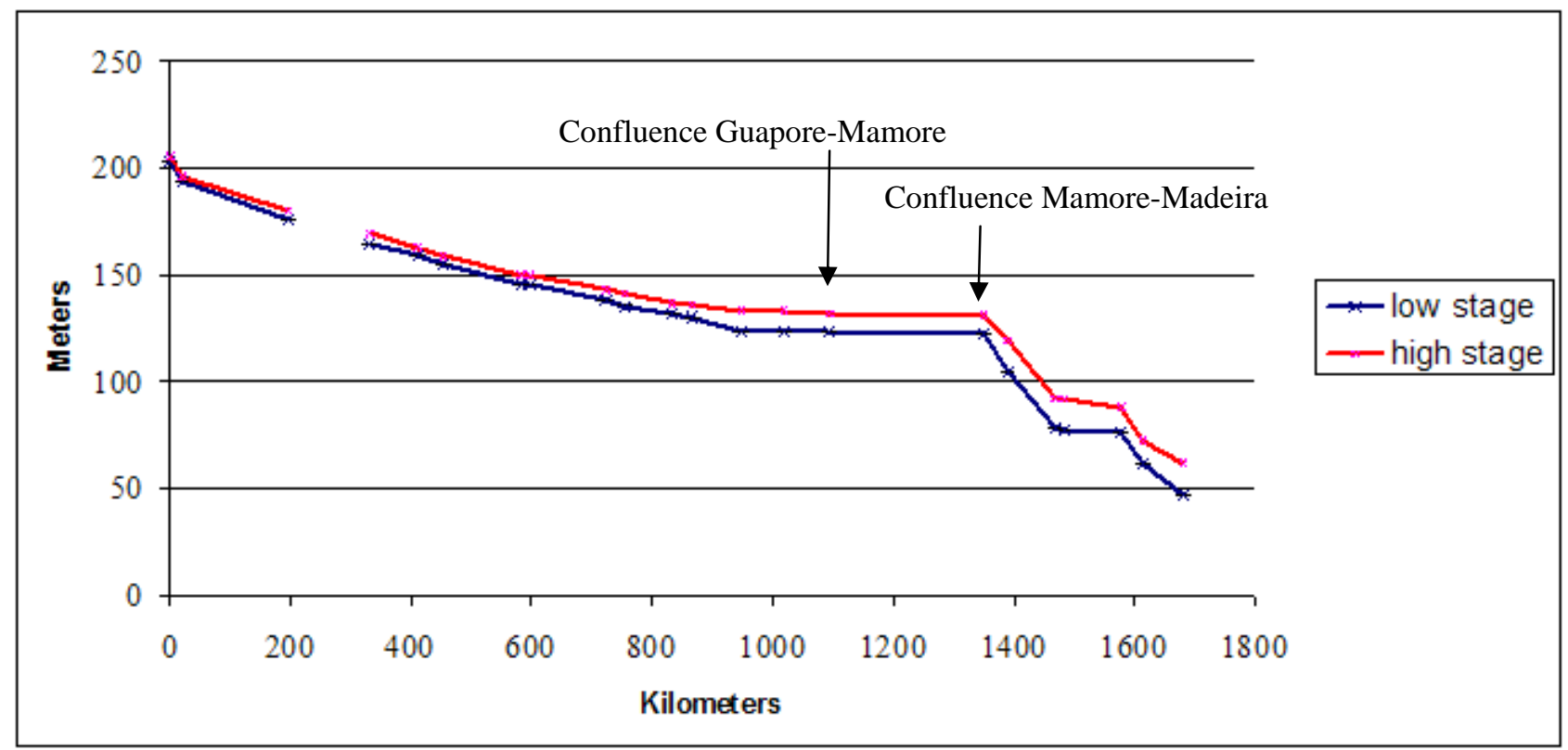

Figure 15 : Elevation profile of the Guapore-Mamore-Madeira rivers

Low Mamore and low Guapore are controled by the water stage of the Madeira river, almost 400 kms upstream at low stage and $250 \mathrm{kms}$ upstream at high stage. There are three successive knick-points on the Guapore, each one located right after the locations where the river is cutting through outcrops of the Brazilian shield. 


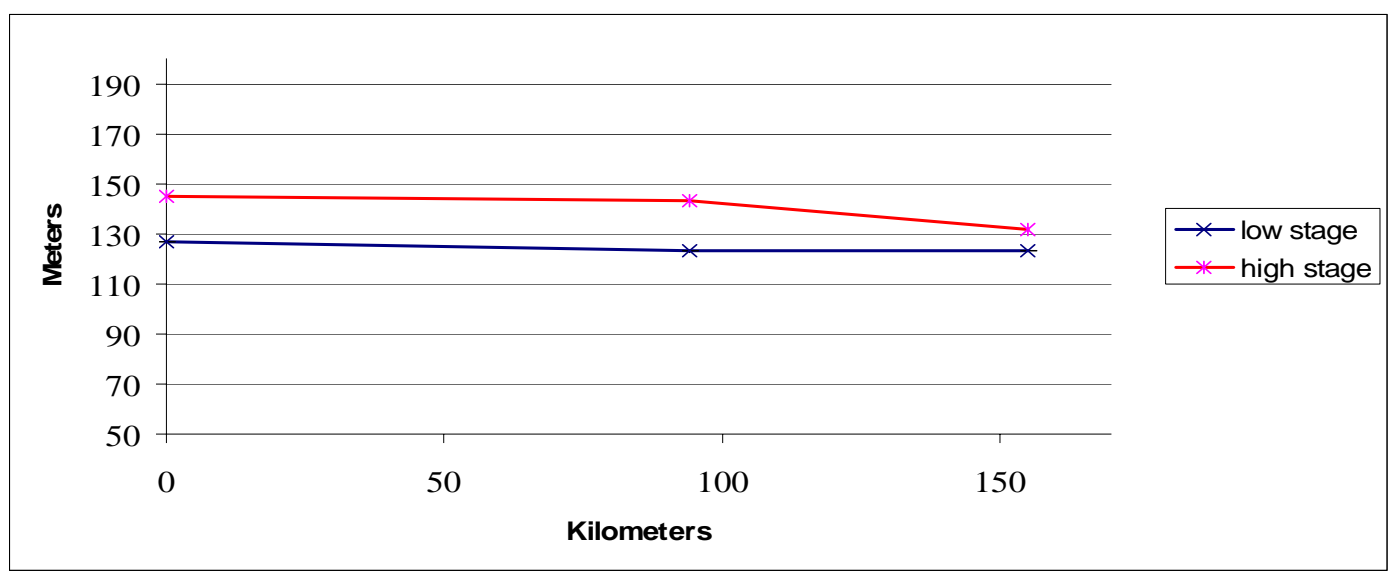

Figure 16 : Elevation profile of the Pacaas Novas river

In contrast, the elevation profile of the Pacaas Novas river is almost flat, totally controlled by the Mamore river at high stage, and slightly flowing at low stage.

\section{CONCLUSION}

Only 8 conventional gauges are recording water stages for the $1750 \mathrm{kms}$ river system formed by the Guapore, the upper Mamore and the upper Guapore from Vila Bela de Santissima Trindade to Porto Velho. 25 « virtual gauges » have been created on the same water course from altimetric data recorded by the radar altimeter RA2 onboard ENVISAT. Several others have been created over lakes, swamps and floodplains related to the Guapore river. The validation of the time series obtained at the virtual gauges have allowed to assess that radar altimeter can monitor correctly the seasonal fluctuation of water stage. The width of the river is not the only criteria to take into account to predict the reliability of the time serie. Rivers less than 100 meters wide can be sampled, provided that they are surrounded by a floodplain, even covered by flooded forest. Steep relief near and before (in the path direction) the river, steep longitudinal slope, islands, flow direction along track are major impediment to the obtention of a reliable time serie. Except these situations, where it is understandable that no reliable altimetric record could be obtained, all the other mismatch between altimetric and conventional time series have hydrological explanations : Joining in of a tributary, loss of water in a derivation flow, or large floodplain slighly dephased in relation to the mainstream. Amplitude of water stage seasonal variation smaller than 2 meters can be successfully recorded by the altimeter. Three major applications are presented in this paper : levelling of the conventional water gauges ; study of the relationship between the river and its floodplain and between the river and the swamps and wetlands of its watershed; study of the elevation profile and river slope. The two last applications are very difficult to monitor in situ, and the recent use of altimetric data have opened entirely new perspectives in the hydrological science field. In this prospect, the SWOT mission, which will be launched around 2015, and will provide a global, quasi-continuous measurement of water surface area and elevation, will provide very valuable new data sets. A lot of improvements are yet to be achieved to process the existing data, and it is necessary to carry on other validation works in distinct environment. But as they are today, the radar altimetric data are useful to open up these new fields of hudrological application.

\section{REFERENCES}

[1] Gleick, P.H. « Global freshwater resources : Soft-path solutions for the 21st century ». Science, 302, 1524-1528, (2003).

[2] Richey, J.E., Melack, J.M., Aufdenkampe, A.K., Ballester, V.M., Hess, L.L. Outgassing from Amazonian rivers and wetlands as a large tropical source of atmospheric CO2, Nature, 416, 617-620, (2002).

[3] Alsdorf, D.E., Rodriguez, E., Lettenmaier, D.P. « Measuring water surface from space ». Reviews of Geophysics, 45, $1-24,(2007)$.

[4] http://www.earthobservations.org/geoss_wa.shtml 
[5] Ronchail, J., Bourrel, L., Cochonneau, G., Vauchel, P., Phillips, L.,Castro A., Guyot, J.-L., de Oliveira, E. «Inundations in the Mamore basin (south-western Amazon-Bolivia) and sea-surface temperature in the Pacific and Atlantic Oceans ». Journal of Hydrology, 302, 223-238, (2005).

[6] Roche, M.A., Fernandez, C. « Water resources, salinity and salt yields of the rivers of the Bolivian Amazon ». Journal of Hydrology, 101, 305-331, (1988).

[7] Siqueira, P.; Hensley, S.; Shaffer, S.; Hess, L.; McGarragh, G.; Chapman, B.; Freeman, A. « A continental-scale mosaic of the Amazon basin using JERS-1 SAR ». IEEE Transactions on Geoscience and Remote Sensing, 38(6), 2638 2644,(2000).

[8] www.ana.gov.br

[9) Lee-L. Fu, Cazenave, A. Satellite Altimetry and Earth Sciences. A handbook of Techniques and Applications, Ed Academic Press, International Geophysics Series, Vol. 69, San Diego, USA , (2001).

[10] Dow, J. M., Martinez Fadrique, F. M., Zandbergen, R. « High precision altimetry from the ENVISAT mission. Advances in Space Research », 23(4), 757- 762, (1999).

[11] Zelli, C. « ENVISAT RA-2 advanced radar altimeter: Instrument design and pre-launch performance assessment review ». Acta Astronautica, 44, 323- 333, (1999).

[12] http://www.legos.obs-mip.fr/fr/soa/altimetrie/

[13] Frappart, F., Calmant, S., Cauhope, M., Seyler, F. and Cazenave, A. « Preliminary results of envisat ra-2-derived water levels validation over the amazon basin ». Remote Sensing of Environment, 100(2), 252-264, (2006).

[14] Wingham, D. J., Rapley, C. G., Griffiths, H. « New techniques in satellite altimeter tracking systems ». Proceedings of IGARSS'86 Symposium, Zurich, 8-11 Sept. 1986, Ref. ESA SP-254, 1339-1344, (1986).

[15] Bamber, J. L. « Ice sheet altimeter processing scheme. International Journal of Remote Sensing, 15(4), 925-938, (1994).

[16] Roux, E., Santos da Silva, J., Vieira Getiranaa, A. C., Bonnet, M.-P., Calmant, S., Seyler, F. « Producing timeseries of river water height by means of satellite radar altimetry - Comparison of methods ». In revision at Hydrological Sciences Journal - Journal des Sciences Hydrologiques.

[17] Smith, L.C. « Satellite remote sensing of river inundation area, stage and discharge, a review ». Hydrological processes, 11, 1427-1439, (1997).

[18] Richards, J.A., Woodgate, P.W., Skidmore, A.K. « An explanation of enhanced radar backscattering from flooded forest ». International Journal of Remote Sensing, 8, 1093-1100, (1987).

[19] Hess, L.L., Melack, J.M., Simonett, D.S. « Radar detection of flooding beneath the forest canopy : a review ». International Journal of Remote Sensing, 11(7), 1313-1325, (1990).

[20] Santos da Silva, Corrêa Rotunno Filho, O.J., Roux, E., Seyler, F., Calmant, S. « Níveis d’água nas zonas úmidas da bacia Amazônica estimadas por satelites altimétricos . II sympósio de Recursos Hidricos do Sul-Sudeste, 12-18 Outubro de 2008, Rio de Janeiro, (2008).

[21] Calmant S., Seyler, F.,. « Continental surface water from satellite altimetry». C.R. Geosciences, 338, 1113-1122, (2006).

[22] Calmant, S., Seyler, F., Créteaux, J.F. « Monitoring Continental Surface Waters by Satellite Altimetry ». In revision at Survey in Geophysics

[23] Tapley, B.D., Bettadpur, S., Watkins, M., Reigber, C. « The gravity recovery and climate experiment: mission overview and early results ». Geophys. Res. Lett. 31, (2004).

[24] Kosuth, P., Blitkow, D., Cochonneau, G. « establishment of an altimetric reference network over the Amazon basin using satellite radar altimetry (Topex Poseidon) ». On 15 years of Progress in Radar Altimetry, Venice, Italy, ESA SP614 July 2006, 8p, (2006). 